УДК: 35.082 .4

DOI https://doi.org/10.32851/tnv-pub.2021.2.4

\title{
РЕЗУЛЬТАТИВНІСТЬ ПУБЛІЧНОГО УПРАВЛІННЯ ТРАНСФОРМАЦІЄЮ ЕКОНОМІЧНОЇ СИСТЕМИ УКРАЇНИ
}

\author{
Зубенко В.В. - кандидат юридичних наук, доцент, \\ доцент каферери публічного управління та адміністрування \\ Херсонського державного аграрно-економічного університету
}

Визначено неохідність вжиття результативних форм управління процесом трасформацій національної економіки Украӥни. Доведено ефективність публічного управління економічними процесами, щзо базується на засадах иілісності, злагодженості, відкритості, демократії, варіантності, оптимальності. Визначено принципи формування моделі трансформацій економічної системи України та ї̈ складові елементи. Встановлено щільність взаємозв'язків між складовими економічної системи та форми звязків. Аргументовано доведено синергетичну природу результативності публічного управління трансформаціями економічної системи складових моделі трансформацій. Визначено ступень результативності публічного управління трансформацією економічної системи Украӥни, щзо доведено фактичними показниками ефективності галузей національної економіки.

Ключові слова: публічне управління, результат, трансформація, економічна система, структура.

Zubenko V.V. The effectiveness of public administration in the transformation of the economic system of Ukraine

The necessity of taking effective forms of management of the process of transformations of the national economy of Ukraine is determined. The efficiency of public management of economic processes based on the principles of integrity, coherence, openness, democracy, variability, optimality is proved. The principles of formation of the model of transformations of the economic system of Ukraine and its constituent elements are determined. The density of interrelations between the components of the economic system and the form of connections is established. In the course of the research it was determined that the application of the principles of public administration brings the economic system to a new level of existence and promotes the formation of a synergetic model of its transformations. Modern conditions of transformation of the national economy require consideration of the principles of organization and selforganization, which actualizes the principles of public administration: legality, objectivity, democracy, science, efficiency, publicity, separation of powers. It is established that mathematical modeling of the process of transformation of Ukraine's economy should be carried out using a systematic approach, which allowed to consider the object of study as a system that is a set of interacting indivisible elements, which should be managed on the basis of law and publicity. The transformation of the national economy is a complex process, and its course leads to its irreversible qualitative development. In terms of research, the internal structure of the national economy is of great interest from the standpoint of changing it over time and establishing the decisiveness in this case of the factor of public administration. The experience gained in this area of application of such models shows their importance in the process of determining macroeconomic patterns, as well as the possibility of their use to predict the likely consequences of macroeconomic decisions while maintaining existing relationships. The synergetic nature of the effectiveness of public management of transformations of the economic system of the components of the transformation model is proved. The degree of effectiveness of public management of the transformation of the economic system of Ukraine is determined, which is proved by the actual indicators of efficiency of the national economy.

Key words: public administration, result, transformation, economic system, structure.

Постановка проблеми. Основою моделювання економічної системи України, як основи держави, є глобальна, загальнолюдська, соціальна, екологічна синергетична парадигма XXI ст. У зв'язку з цим механізм управління моделю нової форми є завданням підвищеного рівня складності, оскільки головною особливістю такої 
відкритої нелінійної системи є ускладненість поділу факторів на першочергові, другорядні та неважливі. У цьому контексті швидкозмінність зовнішніх факторів обумовлює різку зміну ієрархічності впливових факторів, а непередбачувані обставини починають відіграють ключову роль в обранні подальших напрямів розвитку системи.

Аналіз останніх досліджень і публікацій. У розв'язанні проблем трансформацій наукову цінність мають дослідницькі здобутки засновників теорії синергії Е. Лоренца, Р. Фейнмана, Г. Хакена, І. Пригожина, В.-Б. Занга, Р. Євстєгнєєва, Л. Євстєгнєєвої, С. Капиці, С. Курдюмова, а також праці Є. Ходаківського, Н. Гржевської, Л. Мусаєва та ін. Базові положення синергетичного підходу дозволяють сформувати комплексний підхід визначення результативності публічного управління трансформацій економічної системи України.

Формулювання цілей статті. Установлено, що математичне моделювання процесу трансформацій економіки України має здійснюватися за допомогою системного підходу, що дозволяло розглядати об'єкт дослідження як систему, яка являє собою сукупність взаємодіючих неподільних елементів, управління якими має здійснюватися на засадах права та публічності. Отриманий у цьому напрямі досвід надає можливості прогнозування імовірних наслідків макроекономічних рішень за умов збереження існуючих взаємозв'язків.

Виклад основного матеріалу. Математичний формалізм теорії розвитку виключає феноменологічну складову задач управління реальними об'єктами і системами. Слід враховувати обмеження відносно передбачуваності, яка ускладнюється неточністю навіть на початковому етапі існування. Варто наголосити, що сучасні дослідження та пошуки ефективних систем публічного управління слід розглядати $з$ позиції верховенства права та самоорганізації економічних складових системи, які направлені на самозбереження, розвиток та прехід на новий рівень еволюції суспільства. У разі суттєвих змін форми, типу, виду та ступеня тісноти відносин необхідно поновлювати та будувати нову динамічну модель. Сучасні відносини вимагають нових змінних для опису їх у системі, що передбачає розширення методів опису. У результаті система моделей виключає принцип спадковості. В свою чергу елементи системи здобувають риси, схильні до зміни у часі з встановленням вертикальної та горизонтальної ієрархії. Високий ступінь імовірності перебігу цих змін формується під впливом зовнішніх факторів, тоді елементи здобувають інші якісні характеристики та функції, що унеможливлює чітке визначення цілей оновленої системи. У такому випадку досвіду традиційного моделювання недостатньо, тому актуальним стає перехід від моделі до реальності $[1 ; 2 ; 3]$.

У процесі проведених досліджень було визначено, що вжиття принципів публічного управління виводить економічну систему на новий рівень існування та сприяє утворення синергетичної моделі і1ї трансформацій. Сучасні умови трансформацій національної економіки вимагають врахування принципів організації та самоорганізації, що актуалізує приципи публічного управління: законність, об'єктивність, демократія, науковість, ефективність, публічність, поділу влади.

Трансформація національної економіки є складним процесом, а її перебіг приводить до його незворотнього якісного розвитку. В аспекті проведених досліджень значний інтерес викликає внутрішня структура національної економіки 3 позиції зміни іiі у часі та встановленні вирішальності у цьому разі фактору публічного управління. Ми поділяємо думку прихильників синергетичної парадигми економічних досліджень, які стверджують, що складність економічної системи 
характеризується високим рівнем ії самоорганізації, визначаючи саморганізацію результатом переходу з хаосу у порядок за умови дотримання норм права та збереження принципу публічності управлінських рішень [4; 5].

У сучасних умовах розвиток національної економіки України характеризується уніфікацією перетворень структури та функцій, що потребує використання абстрактного відображення ізоморфізму у вигляді моделей, а відповідна математична формалізація дозволяє досягти реалістичності, цілісності, точності, що передбачає використання наукових здобутків різних галузей науки, включаючи прогнозування розвитку соціально-економічних систем [1]. Визначаючи результативність моделі трансформацій національної економіки доведено, що трансформаційні процеси економічної системи України є складними, оскільки вплив зовнішніх факторів та внутрішніх суб'єктів має короткострокову дію, характеризується відсутністю системності та передбачуваності, а очікуваний ефект обмежується. Відповідно, очікуваний ефект, як складова результативності, є короткостроковим та підпорядковується інтересам окремих суб'єктів, що позбавляє можливості національну економічну систему вийти на шлях самоорганізації у рамках правого поля та на засадах публічності.

У цьому контексті моделі трансформацій економічної системи України має базуватися на ключових принципах, серед яких принцип цілісності, комплексності, компліментарність, злагодженості, варіантності, оптимальності, своєчасності та відкритості. Зокрема, принцип цілісності полягає в тому, що економічні елементи мають певний рівень самостійності, визначений чинним законодавством та грунтується на засадах публічності.

В рамках синергетичного підходу основним результатом цих елементів $\epsilon$ не тільки економічний результат, а також результат спільної взаємодії, що буде мати економічне, фінансове, соціальне, інституційне та культурне вираження. Важливим принципом побудови моделі трансформацій економічної системи є принцип комплексності та злагодженості, що передбачає усунення протиріччя між спільними діями елементів економічної системи за допомагою правового механізму державного управління та елементів публічності управлінських рішень.

Побудова моделі трансформацій економічної системи передбачає значну кількість напрямів розвитку, що включає значну кількість варіантів. Це ускладнює прогнозування, а багатоваріантність - виключає передбачуваність подальших трансформаційних перетворень. Така ситуація має орієнтувати на подальший розвиток системи, який може реалізовуватися шляхом деградації та руйнації старої системи, що є основою для утворення нової за посиленням нормативно-правового та організаційного мезанізму державного управління.

Головною умовою формування моделі трансформацій економічної системи $\epsilon$ оптимальне використання існуючих ресурсів 3 максимальною результативністю. У цьому контексті важливим є принцип своєчасності, що потребує визначення рівня економічної ефективності з метою переходу на новий трансформаційний етап. Публічне управління є механізмом реалізації синергетичної моделі економічної системи, що має базується на принципі відкритості.

Результативність моделі трансформацій економічної системи буде виражатися відтворювальною, економічною, інтеграційною, екологічною, соціальною, культурною, світоглядною іiі функцією. Вважаємо, що у моделі має бути закладено не тільки економічний характер трансформаційних перетворень, а й охоплено зовнішнє середовище в межах інтеграції світової економіки, екологічну ситуацію, соціальні проблеми, культурні цінності. 
Під впливом зовнішнього середовища синергетичний ефект від трансформаційних перетворень, як правило, кількісно та якісно змінюється у вигляді розширення міжнародної торгівлі та зміцнення політичних зв'язків. Слід зазначити, що взаємодія складових аграрного сектору економіки утворює додатковий ефект за принципом взаємодоповнення та компліментарності, у результаті яких виокремлюються додаткові фінансові ресурси, що можуть бути використані в якості інвестицій при вдалій співпраці в межах світового економічного простору. Наприклад, взаємодія інвестиції та політичних складових формує нормативно-правові, законодавчі та дипломатичні умови для реалізації додаткового виробництва сільськогосподарської продукції на міжнародних ринках. Таким чином, посилення позиції України як експортної держави, робить ії гарантом продовольчої безпеки світу, що дозволить залучити додаткові інвестиції у виробництво і переробку сільськогосподарської продукції з подальшим розвитком науки та технологій.

Крім цього, прикладом формування синергії від взаємодії складових аграрного сектору слід вважати взаємодію інституційних та соціальних компонентів 3 утворенням економічно обгрунтованої демографічної політики, вирішенням проблем працевлаштування та забезпеченості наукового підхіду до низки соціальних питань. Як наслідок формується нова форма громадського суспільства, що покликане підвищити продуктивність праці, дотримання норм громадського права та прав людини [7].

Поєднання соціальної та фінансово-кредитної складових слід вважати класичним прикладом прояву синергетичного ефекту. Оскільки свідоме громадське суспільство, яке характеризується високим рівнем продуктивності праці, значним рівнем освіти та свідомості, потребує залучення додаткових фінансових ресурсів у галузі освіти, охорони здоров'я, будівництва тощо. Тому фінансовими установами визначається необхідність кредитування населення відповідно до визначених пріоритетів.

Визначений нами синергетичний ефект публічного управління у формуванні нової економічної системи України окреслюється багатоваріантністю зв'язків різних складових, що визначає значну кількість ефектів від їх взаємодії. Зокрема, результатом політичної та економічної складової має бути удосконалення механізмів управління національною економікою, що визначається нормативно-правовими нормами регулювання діяльності господарського комплексу. Доведено, що вплив кожної окремої складової, насамперед політичної, інституційної, соціальної та екологічної на обсяг виробництва продукції, наприклад аграрного сектору, як впливової компоненти національної економіки, відсутній.

Висновки. Визначення результативності публічного управління трансформацією економічної системи України доведено фактичними показниками ефективності галузей національної економіки, зокрема, сільського господарства, як ведучої галузі. Соціальним ефектом моделі є покращення якості життя, зростання загальнонаціонального рівня освіти, подолання безробіття, підвищення загальнокультурного рівня тощо. Тоді як зовнішньоекономічним синергетичним ефектом повинно бути посилення і покрашення якості міжнародних зв'язків, полегшення інтеграційних процесів, поглиблення культурних зв'язків, полегшення вступу до світових організацій та інше. Фінансово-інвестиційна природа синергетичного ефекту має виражатися у реалізації інноваційних проектів, підвищення ефективності державної підтримки.

\section{СПИСОК ВИКОРИСТАНОЇ ЛІТЕРАТУРИ:}

1. Капица С.П., Курдюмов С.П., Малинецкий Г.Г. Синергетика и прогнозы будущого. Київ : 2003257 с. 
2. Левашов В.К. Глобализация и устойчивое развитие. Устойчивое развитие. Наука и Практика. 2002. № 1. С. 19-38.

3. Леонтьев В. Исследования структуры американской экономики. Москва: Прогресс, 1958. 720 с.

4. Лесков Л.В. Постижение непредсказуемого: бифуркационное пространство XXI века. Общественные науки и современность. 2001. № 6. С. 167-175.

5. Петров Л.Ф. Методы нелинейной динамики как инструменты управления экономической эффективностью. С. 1-11. URL: http://www.info.e-c-m.ru/ UER_23_03_2011.pdf.

6. Потравка Л.О. Модель трансформацій аграрного сектора України. Науковий вісник Міжнародного гуманітарного університету. Серія: Економіка і менеджмент. 2016. Вип. 20. С. 40-46.

7. Потравка Л.О. Оцінка синергетичного ефекту структурних трансформацій агропродовольчого сектора України. Вісник Одеського національного університету ім. I.I. Мечникова. 2015. Вип. 19. Т. 20. С. 71-74.

8. Nemchenko D., Kobets V., Potravka L. Neuro-fuzzy model of development forecasting and effective agrarian sector transformations of Ukraine. CEUR Workshop Proceedings. 2018. 2104, P. 84-99.

\section{REFERENCES:}

1. Kapica S.P., Kurdyumov S.P., Malineckij G.G. Sinergetika i prognozy budushogo. Kyiv: 2003257 s. [in Ukrainian].

2. Levashov V.K. Globalizaciya i ustojchivoe razvitie. Ustojchivoe razvitie. Nauka i Praktika. 2002. № 1. S. 19-38. [in Russian].

3. Leontev V. Issledovaniya struktury amerikanskoj ekonomiki. Moscow: Progress, 1958. 720 s. [in Russian].

4. Leskov L.V. Postizhenie nepredskazuemogo: bifurkacionnoe prostranstvo XXI veka. Obshestvennye nauki i sovremennost. 2001. № 6. S. 167-175. [in Russian].

5. Petrov L.F. Metody nelinejnoj dinamiki kak instrumenty upravleniya ekonomicheskoj effektivnostyu. S. 1-11. Retrieved from http://www.info.e-c-m.ru/ UER_23_03_2011.pdf. [in Russian].

6. ${ }^{-}{ }^{-}{ }^{-}{ }^{-}$kna L.O. Model transformacij agrarnogo sektora Ukrayini. Naukovij visnik Mizhnarodnogo gumanitarnogo universitetu. Seriya: Ekonomika i menedzhment. 2016. Vip. 20. S. 40-46. [in Ukrainian].

7. Potravka L.O. Ocinka sinergetichnogo efektu strukturnih transformacij agroprodovolchogo sektora Ukrayini. Visnik Odeskogo nacionalnogo universitetu im. I. I. Mechnikova. 2015. Vip. 19. T. 20. S. 71-74 [in Ukrainian].

8. Nemchenko D., Kobets V., Potravka L. Neuro-fuzzy model of development forecasting and effective agrarian sector transformations of Ukraine. CEUR Workshop Proceedings. 2018. 2104, P. 84-99 [in Ukrainian]. 